"The relationship among change implementation, job satisfaction and organizational citizenship behavior in the Business Process Outsourcing industry in South Africa"

\author{
George N. Muzanenhamo \\ AUTHORS Charles O.K. Allen-lle \\ Anthea Adams \\ Chux Gervase Iwu (iD https://orcid.org/0000-0002-6290-9864
}

George N. Muzanenhamo, Charles O.K. Allen-lle, Anthea Adams and Chux Gervase Iwu (2016). The relationship among change implementation, job

ARTICLE INFO satisfaction and organizational citizenship behavior in the Business Process Outsourcing industry in South Africa. Problems and Perspectives in Management, 14(3-2), 473-482. doi:10.21511/ppm.14(3-2).2016.03

DOI http://dx.doi.org/10.21511/ppm.14(3-2).2016.03

RELEASED ON Tuesday, 27 September 2016

JOURNAL

"Problems and Perspectives in Management"

FOUNDER

LLC "Consulting Publishing Company "Business Perspectives"

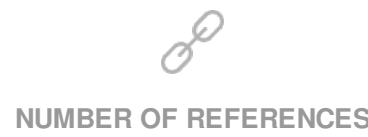

0
NUMBER OF FIGURES

0
NUMBER OF TABLES

$\mathbf{0}$

(C) The author(s) 2022. This publication is an open access article. 
George N. Muzanenhamo (South Africa), Charles O.K. Allen-lle (South Africa), Anthea Adams (South Africa), Chux Gervase Iwu (South Africa)

\title{
The relationship among change implementation, job satisfaction and organizational citizenship behavior in the Business Process Outsourcing industry in South Africa
}

\begin{abstract}
The unique and dynamic Business Process Outsourcing (BPO) industry in South Africa strives to thrive in a challenging business environment with the attendant need for stability, loyal and satisfied workforce. An empirical investigation was, therefore, conducted utilizing managerial and non-managerial employees in a stratified sampling technique. Questionnaires were administered to 250 employees from four selected organizations. The essence was to examine the nature of the relationship among change implementation, job satisfaction and organizational citizenship behavior (OCB). Four significant results emerged. Firstly, there is a positive but moderate relationship between change implementation and $\mathrm{OCB}$; there is a high or strong positive relationship between change implementation and job satisfaction; there is a positive, but moderate relationship between OCB and job satisfaction; and lastly the results confirm the assumption that job satisfaction moderates the relationship between change implementation and OCB. BPO firms need to understand the effects of change implementation on OCB and job satisfaction. This is because change management is inevitable in the BPO industry; therefore, organizations have to be constantly alert to tackle its demands.
\end{abstract}

Keywords: change management, job satisfaction, intrinsic job satisfaction, extrinsic job satisfaction, organizational citizenship behavior.

JEL Classification: J240, J280, L240, M120.

\section{Introduction}

Developing a workable formula for achieving and sustaining organizational superiority has become one of the most multifaceted tasks faced by organizations today. Amid the tide of globalization, one of the major challenges confronting the human resources professional is gaining a competitive advantage in the rapidly changing environment of personnel management.

A great many organizations are embarking on complex changes such as shared services, transformation, mergers and acquisition, and massive technology implementation. For many managers and entrepreneurs, organizational changes constitute a nightmare. In some instances, there is no single structure which will enable a given change to be managed within an enterprise and, as a consequence, the implementation of change slows down, and can even stall or fail completely. Conversely, there are huge potential gains for organizations which are able to effectively facilitate the successful implementation of change in terms of delivering them on time, within an allotted budget, and with all the business, technical and human objectives met.

(C) George N. Muzanenhamo, Charles O.K. Allen-Ile, Anthea Adams, Chux Gervase Iwu, 2016.

George N. Muzanenhamo, Post-graduate Student, Faculty of Business \& Management Sciences, Cape Peninsula University of Technology, South Africa.

Charles O.K. Allen-Ile, Ph.D., Department of Industrial Psychology, University of the Western Cape, South Africa.

Anthea Adams, M.A. M.Ed., Faculty of Business \& Management Sciences, Cape Peninsula University of Technology, South Africa.

Chux Gervase Iwu, Ph.D., HoD., Faculty of Business \& Management Sciences, Cape Peninsula University of Technology, South Africa.
$\mathrm{BPO}$ is the practice of contracting (or outsourcing), often a critical operation or responsibility of an organization to a third-party service provider. It is not uncommon to find big (multinational manufacturing) firms conducting business in this form. The value for these firms is that it allows them to focus on their core competencies. It is, therefore, not unusual for matters such as information security (risk), employee loyalty, employee attitudes to broad organizational values to arise. Essentially, the need to contain change in the BPO industry in South Africa has resulted in employees becoming more organized, sophisticated and unpredictable. Consequently, determining their needs and expectations has become a complex and daunting task. The behavior of organizations changes continuously, as they undergo revolutionary changes. For any organization, the ideal is usually perceived to involve striving for a single standard change management methodology with a single unifying vocabulary; but, more often than not, the complex pressure to meet diverging demands of employees within organizations has tended to preclude the adoption of the unified approach required to implement effective changes.

Both internal and external forces such as market changes, technological advancements, social and political factors, demographic characteristics, managerial behavior or decisions and human resources problems or prospects exert tremendous pressure in the scramble for organizational success today, making change inevitable (Kreitner \& Kinicki, 2004, p. 674). At present, the efforts and resources of organizations are subject to pressure from two directions, namely 
meeting, if not exceeding, the needs and expectations of employees, and achieving a competitive edge. No matter how change is defined, the principal challenge for organizations remains the effective management of balancing the demands and expectations among stakeholders, including customers, employees, management and shareholders. If this delicate balance is not achieved, organizations in the BPO industry risk breeding an anxious workforce, with diminishing productivity as a likely consequence.

Promoting positive behavioral attitudes, and safeguarding the welfare of employees are crucial dynamics to be managed in organizational advancement; and the variables in the workplace which have assumed greatest prominence are job satisfaction, the degree of employee involvement in their jobs and their commitment to the organization. Of particular significance in the last two decades has been the emergence of organizational citizenship behaviors (OCB) as a formalized manifestation of these variables.

Accordingly, it needs to be stressed that employees' attitudes towards organizational change affect not only the success of the process of change, but other important considerations for organizations, such as employees' job satisfaction, and commitment to and involvement in their work. Change can threaten comfortable established relationships, and often introduces the possibility of job loss or at least of changes with respect to the type of work to be undertaken by employees and their status within an organization. As a result, if organizational changes are not well managed, they can become a source of great job dissatisfaction among employees. For this reason, encouraging workers to exhibit desirable OCB when they are highly dissatisfied could become an extremely frustrating exercise.

\section{Study objectives:}

- To explore the nature of change implementation in the BPO industry.

- To determine the effects of change implementation on OCB and job satisfaction in the BPO industry.

- To explore the relationship between change implementation, OCB and job satisfaction.

Inspiration of the study: at present, the BPO industry in South Africa is failing to sufficiently implement initiatives for change, which results in low levels of OCB and, correspondingly, low levels of job satisfaction.

\section{Research questions:}

- What is the nature of the implementation of change in the BPO industry?
- What are the effects of the implementation of change on OCB and job satisfaction in the $\mathrm{BPO}$ industry?

- Does a relationship exist between the implementation of change, OCB and job satisfaction?

\section{Literature review}

This review will briefly focus on the key concepts in this paper namely organizational change, organizational citizenship behavior (OCB) and job satisfaction.

1.1. Organizational change. Several meanings available in literature make defining organizational change a difficult task (Wood, 2000, p. 1). According to Terry and Jimmieson (2003, p. 92), unprecedented rearrangements around organizational surroundings trigger the need for organizations to change familiar traditions and methods of operation. These alterations influence the organizational life and behavior of the labor force.

For Porras and Robertson (1992, p. 719), the concept of organizational change involves the adoption of fixed proven hypotheses of principles, tactics and methods aimed at changing the work environment, thereby stimulating the organization's development. Despite the heterogeneous definitions available to characterize organizational change, with reference to Wood (2000, p. 1), change can be understood as having the potential to impact an organization structurally and strategically, while impacting the workplace culture, affecting human capital and seeing technological transformation.

1.2. Change management initiatives. According to Kotter (1995, p. 59), as many as $90 \%$ of change initiatives are likely to fail to achieve their strategic objectives, mainly as a result of human factors such as change-related responses, attitudes and behaviors. Kanter (1983, p. 19) explains that the emotional responses of employees to organizational change often includes feelings of uncertainty and anxiety, particularly in relation to how the change is likely to affect their job security, the nature of their work, career path, co-worker relations and reporting relations. In light of the above, change cannot occur unless and until change management initiatives are well administered and people have made a conscious decision to change.

Although there are many other phase-models which deal with the implementation of organizational change, for the purpose of this study and cognizant of the nature of the BPO industry in South Africa, attention will be given to a research framework developed by Isa et al. (2011, p. 109) who explored the correlation between change management 
initiatives and job satisfaction among salespersons in the direct selling industry of Malaysia, as illustrated in Figure 1. Isa and her colleagues developed six change management initiatives or variables paramount to change success and job satisfaction.

\section{Change management initiatives}

1. Shared change vision

2. Communication

3. Upline support

4. Compensation systems

5. Training

6. Feedback

Fig. 1. Change management initiative model

Source: Isa et al. (2011, p. 109).

In short, change must be well articulated and communicated across the board for larger buy-in by stakeholders. This will ensure that resistance to the change efforts is minimal. It is also critical to have top management support. It must be noted that upline support is likely to exert influence on downline so as to be cooperative and participative (Weber \& Weber, 2001).

Studies have shown that reinforcement and compensation for change stimulates employees to voluntarily support change initiatives, which, consequently, enhance organizational competitiveness (Vanyperen et al., 1999, p. 377). Organizations are, therefore, required to consider offering their employees a wide range of rewards as a way of encouraging them to perform and accept change (Appelbaum et al., 1998, p. 674). Training is more effective when the reason for change is properly communicated as it assists employees to know how to effectively tackle change through knowledge and skills sharing (Isa et al., 2011, p. 111). Then, finally, participants in the change program need to be informed about progress and development occurring. Therefore, feedback should be used as an instrument to measure change more often.

1.3. Organizational citizenship behavior (OCB). According to Schultz et al. (2003, p. 221), the term OCB refers to behaviors of employees which are outside the scope of approved organizational norms. They are normally referred to as extra-role behaviors and can easily be detected by peers, managers and researchers. Cross, Rebele and Grant (2016) refer to those who exhibit these behaviors as 'extra milers'.

Taking from the groundbreaking work by Chester Barnard (1938, p. 5) regarding the "willingness to cooperate", and Daniel Katz (1964, p. 132) discrepancy between "dependable role performance" and "innovative and spontaneous behaviors", Organ (1988, p. 4) defines organizational citizenship behavior as "individual behavior which is discretionary, not directly or explicitly recognized by the formal reward system, and which in the aggregate promotes the effective functioning of the organization. By discretionary, we mean that the behavior is not an enforceable requirement of the role or the job description, which is, the clearly specifiable term of the person's employment contract with the organization; the behavior is rather a matter of personal choice, such that its omission is not generally understood as punishable".

Kreitner and Kinicki (2004, p. 213) view OCBs as involving three major components: they exceed the role requirements of an employee's job; they are discretionary in nature, that is, employees decide to perform them in a voluntary manner; and, finally, they are not part of the normal compensation management system. According to Organ (1997, p. 85), OCB is also known as "the good soldier syndrome". He organizes OCB into five common themes or gestures, namely, altruism, civic virtue, conscientiousness, sportsmanship and courtesy. Another name given to these gestures is OCB dimensions. Notwithstanding the abundance of OCB definitions at hand, OCBs can be simply defined as voluntary or choice behaviors which surpass the expected or prescribed norms, values and roles which indirectly benefit the organization.

OCB can be two-pronged: directed at an individual or at an organization. According to Williams and Anderson (1991, p. 601), OCBI denotes workplace behaviors directed towards certain individuals, and directly benefits those individuals and indirectly enhance organizational success. For Podsakoff et al. (2000, p. 513), OCBI are behaviors directed towards helping colleagues who require help to fulfill their work functions. Likewise, Borman (2004, p. 239) affirms that citizenship behavior directed towards individuals involves offering contributions in the form of suggestions to others, imparting relevant knowledge and skills to others, executing others' job functions, and prioritization of group objectives in comparison to individual interests and gains. 
With respect to OCB directed towards the organization (OCBO), an example can be cited when employees voluntarily chose to obey organizational policies and procedures or volunteer to be members of company work groups (Williams \& Anderson, 1991, p. 601). According to Podsakoff et al. (2000, p. 513), this type of OCB requires employees to familiarize themselves with company rules and regulations.

1.4. Job satisfaction. Job satisfaction as a construct has been widely researched over the past decades. The complexity of the concept and its wide-ranging facets cannot be sufficiently addressed by a single hypothesis (Chou \& Robert, 2008, p. 208). "It can be the cause of behavior, part of a behavior cycle, or part of a regulatory system" (Faulkenburg \& Schyns, 2007, pp. 708-725). Indeed, "it is an extent to which one feels positively or negatively about the intrinsic and/or extrinsic aspects of one's job" (Boles et al., 2007, p. 312).

In 1976, Locke proposed one of the most important definitions of job satisfaction: "a pleasant or positive emotional state resulting from the individual's assessment of the work or work experience" (Locke, 1976, p. 1300). In relation to Locke' definition, job satisfaction is, therefore, an individual's affective reaction to work. Organ and Near (1985) extended the concept of employee satisfaction by adding cognitive and affective components, and have called into question the adequacy of former measures of job satisfaction, with regard to their sensitivity to both components (Kaplan et al., 2009, p. 29).

Following suit, Iwu, Ukpere and Allen-Ile (2012) characterized employee satisfaction as the 'satisfaction derived by an employee from; given his or her own preferences, the positive presence of the facets of job satisfaction and dimensions of organizational culture. This definition seems somewhat related to Chan et al's (2004) who provided a more generalized view of job satisfaction by moving away from linking satisfaction to positive or affective reactions alone and referring to it as an employee's overall assessment of work-related experiences which is influenced by individual values, ideals and beliefs. Thus, job satisfaction is a multidimensional concept which includes a set of favorable or unfavorable feelings in terms of which employees perceive their jobs (Davis, 2004, pp. 495-503).

Recent studies have given birth to numerous other definitions and explanations of job satisfaction, some focused on the job alone, while others include all job-related factors.

1.4. The relationship between change implementation, OCB and job satisfaction. Organizations today are more concerned with the effectiveness of change, and selecting the right methodology to implement it. Contrastingly, employees' expectations and considerations are explicitly dissimilar. The uncertainty employees experience with organizational change, inevitably, has a bearing on their job security, stress levels, trust, commitment, organizational identification, performance, employee work attitude and, ultimately, job satisfaction. As a result, these perceived evaluations affect the relationship between employees and the organizations. In line with this, Mack et al. (1998, pp. 219-232) point out that organizational change transfigures employees' traditional working arrangement. The uncertainties experienced during the change process stimulate job dissatisfaction among employees (Mack et al., 1998).

The manner in which the change process is administered also directly influences employee attitudes in the workplace. Organizational change in this study includes, among others, organizational downsizing, growth, workforce rearrangement, total quality management, job redesign, leadership change, mergers and acquisition, restructuring, business process reengineering and introduction of new technology. The aforesaid types of change influence employee behaviors or attitudes differently and either affect the entire organization or simply specific sections or divisions.

The effects of organizational downsizing are dependent on employees' past experience, particularly with identical transformations. For Svensen et al. (2007, pp. 153-159), if employees have had bad experiences with past changes, their satisfaction levels are likely to be negative. However, if previous changes were perceived as positive job satisfaction is likely to be high. Contrastingly, Cross and Travaglione (2004, pp. 275-290) suggest that job satisfaction is predominantly high after organizational downsizing, because those who are left behind will be more content than the victims of change. However, organizational downsizing increases employees' workload, because the remaining employees will be required to perform their work and that of affected others. Inevitably, the consequence of increased workload manifest in the form of high job dissatisfaction (Karasek, 1979, pp. 285-308).

Following the above discussion, it is clear that the adverse effects of change are inevitable and include among others anxiety, job insecurity, and stress, loss of social identity, high absenteeism and high labor turnover. These effects are reflected in employees' levels of job satisfaction and have negative psychological connotations on employees.

Organizational identification or satisfaction increases when change is timeously, accurately and openly communicated. Contrastingly, organizational identification or satisfaction decreases when workers lose confidence in the organization because of insufficient information about change. In support, 
Reichers et al. (1997, pp. 48-66) note that when employees greatly comprehend organizational changes, it is highly likely that they tend to easily identify themselves with the organization and also actively participate in change management programes. This, in turn, enhances organizational effectiveness. Griffeth et al. (2000, pp. 577-590) highlight that insecurities about change outcomes lead to job dissatisfaction.

In consonance with the aforementioned, Werner (2004, p. 98) maintains that employees only display extra-role behaviors when they perceive that their organization cares about their wellbeing. In the same line of reasoning, Bateman and Organ (1983) note that the extent to which employees display extra-role behaviors is largely determined by their feeling of satisfaction towards their work, as compared to the support expended by their leaders or colleagues.

Chiboiwa's (2011) findings concur with the aforesaid research findings. His investigations covering administrative employees of five organizations in Zimbabwe established a moderate correlation between $\mathrm{OCB}$ and job satisfaction. Research by Ghazzawi (2008, p. 4) concerning the link between factors that promote job satisfaction or dissatisfaction and the effects or consequences thereof revealed that OCB is an outcome of job satisfaction.

While highlighting the correlation between OCB and job satisfaction, numerous scholars have argued that, to enhance the manifestation of organizational citizenship behaviors in an organization, job satisfaction should be regarded as a mediating or moderating factor. Elaborating upon the aforementioned, Chiu and Chen (2005, p. 523) encourage organizations to create an enabling environment which intrinsically motivates employees and, in turn, stimulates them to display citizenship behaviors.

A number of scholars are, however, still unconvinced about the correlation between OCB and job satisfaction. Adam (2001) points out that the complexion of job satisfaction measures causes the correlation between the two variables to be insignificant or non-existent. However, despite the heterogeneous findings at hand, the assumption that OCB correlates with job satisfaction is widely accepted in the body of organizational behavior.
Following the above discussion, we can, therefore, conclude that the old adage that job satisfaction significantly correlates with OCB still makes sense. Also, whether positive or negative, the relationship between change implementation and job satisfaction hold a knock-on effect on OCB and one can only conclude that, there is a significant relationship between change implementation, OCB and job satisfaction.

\section{Measures}

Two questionnaires were used to gather information on change management, organizational citizenship behavior and job satisfaction. Change management questions were derived from the Attitudes to Change Questionnaire (ACQ) developed by Vakola and Nikolaou (2005). The Minnesota Satisfaction Questionnaire (MSQ) by Weiss et al. (1966, p. 110) was employed to draw up intrinsic and extrinsic job satisfaction questions. For OCB, questions were extracted from the questionnaire developed by Konovsky and Organ (1996, p. 255). OCB questions were subdivided into five facets, namely, altruism, civic virtue, conscientiousness, courtesy and sportsmanship. The measuring instruments have been found to have high reliability coefficient. Research results by Chan et al. (2004, p. 453) reflected that MSQ has strong internal median consistency reliability of 0.83 , whilst the median retest reliability was also 0.83. Van Emmeriki et al. (2005, p. 96) found a strong Cronbach's alpha value of 0.79 for the OCB measuring instrument developed by Konovsky and Organ (1996).

2.1. Method. The research information was collected in 2014 from four organizations in the BPO industry which are based in Cape Town in the Western Cape province of South Africa. Questionnaires were administered to 250 managerial and non-managerial employees who were randomly drawn from the study population using the probability sampling method.

2.2. Results. Of all 250 questionnaires distributed to both managerial and non-managerial employees in the BPO industry, 201 were returned and were usable for subsequent analysis, yielding a response rate of $80.4 \%$. Tables 1, 2, 3 and 4 present the results of the Pearson Product Moment Correlation Matrix indicating the correlation between change implementation, job satisfaction and OCB.

Table 1. Correlation matrix between change implementation and OCB

\begin{tabular}{|l|c|c|c|c|c|}
\cline { 2 - 5 } \multicolumn{1}{c|}{} & Altruism & Civic virtue & Conscientiousness & Sportsmanship & Courtesy \\
\hline Shared vision & 0.219582 & 0.344233 & 0.164749 & -0.486652 & 0.326517 \\
\hline Communication & 0.19542 & 0.338618 & 0.117486 & -0.448282 & 0.308771 \\
\hline Upline support & 0.242689 & 0.301344 & 0.128127 & -0.444456 & 0.287116 \\
\hline Compensation systems & 0.196882 & 0.328461 & -0.023182 & -0.471366 & 0.180962 \\
\hline Training & 0.102559 & 0.364282 & 0.125558 & -0.375002 & 0.309101 \\
\hline Feedback & 0.105308 & 0.282291 & 0.141425 & -0.395955 & 0.288266 \\
\hline
\end{tabular}


With respect to Table 1, it can be seen that there is a positive, but moderate relationship between the majority of change management initiative variables and OCB variables, with the exception of sportsmanship which has a negative correlation with all change variables, and conscientiousness, which recorded a negative relationship only with compensations system $(r=-0,0232, p=0.7711)$. There were significant relationships between shared change vision and altruism $(r=0.2196, p=0.0053)$, civic virtue $(r=0.3442, p=0)$, conscientiousness $(r=0.1647, p=0.0374)$ and courtesy $(r=0.3265$, $p=0)$. Positive relationship was also recorded between communication and altruism $(r=1.954, p=0.0132)$, civic virtue $(r=0.3386, p=0)$, conscientiousness $(r=0.1175, p=0.1390)$ and courtesy $(r=0.3088$, $p=0)$. Upline support recorded a strong correlation with altruism $(r=0.2427, p=0.0020)$, civic virtue $(r=0.3013, \quad p=0.0001), \quad$ conscientiousness $(r=0.1281, p=0.1064)$ and courtesy $(r=0.2871$, $p=0.0002$ ). In addition, there were significant relationships between compensation systems and altruism $(r=0.1969, p=0.0126)$, civic virtue $(r=0.3285, p=0)$ and courtesy $(r=0.1810$, $p=0.0220$ ). Furthermore, training also recorded significant correlations with altruism $(r=0.1026$, $p=0.1969)$, civic virtue $(r=0.3642, p=0)$, conscientiousness $(r=0.1256, p=0.1136)$ and courtesy $(r=0.3091, p=0.0001)$. Lastly, feedback recorded significant correlations with altruism $(r=0.1053, p=0.1551)$, civic virtue $(r=0.2823$, $p=0.0003), \quad$ conscientiousness $(r=0.1414$, $p=0.0744)$, courtesy $(r=0.2883, p=0.0002)$. However, when all the OCB variables are combined as reflected in Table 4, there is still a positive, but weak correlation between change implementation and OCB $(r=0.1904)$.

Table 2. Correlation matrix between change implementation and job satisfaction

\begin{tabular}{|l|c|c|}
\cline { 2 - 3 } \multicolumn{1}{c|}{} & Extrinsic job satisfaction & Intrinsic job satisfaction \\
\hline Shared vision & 0.701132 & 0.59356 \\
\hline Communication & 0.753491 & 0.632876 \\
\hline Upline support & 0.697741 & 0.542619 \\
\hline $\begin{array}{l}\text { Compensation } \\
\text { systems }\end{array}$ & 0.620638 & 0.533068 \\
\hline Training & 0.659433 & 0.562884 \\
\hline Feedback & 0.606531 & 0.499425 \\
\hline
\end{tabular}

The results indicated in Table 2 depict a strong or high positive correlation between the implementation of change initiative variables and job satisfaction variables. With respect to this table, there are significant relationships between extrinsic job satisfaction and shared change vision $(r=0.7011$, $p=0)$, communication $(r=0.7535, p=0)$, upline support $(r=0.6977, p=0)$, compensation systems $(r=0.6206)$, training $(r=0.6594, p=0)$, as well as feedback $(r=0.6065, p=0)$. In addition, there were statistically significant relationships between intrinsic job satisfaction and shared change vision $(r=0.5936$, $p=0)$, communication $(r=0.6329, p=0)$, upline support $(r=0.5426, p=0)$, compensation systems $(r=0.5331, p=0)$, training $(r=0.5629, p=0)$ and feedback $(r=0.4994, p=0)$. After all the variables were combined as highlighted in Table 4 , change implementation and job satisfaction recorded a very strong positive relationship ( $r=0.7644)$.

Table 3. Correlation matrix between change implementation and job satisfaction

\begin{tabular}{|l|c|c|c|c|c|}
\hline & Altruism & Civic virtue & Conscientiousness & Sportsmanship & Courtesy \\
\hline Extrinsic job satisfaction & 0.136522 & 0.341985 & 0.081492 & -0.572679 & 0.270467 \\
\hline Intrinsic job satisfaction & 0.260378 & 0.318447 & 0.09588 & -0.504899 & 0.284687 \\
\hline
\end{tabular}

Table 3 denotes a positive but moderate correlation between OCB variables and job satisfaction variable with the exception of sportsmanship that has a negative correlation with both extrinsic and intrinsic job satisfaction. Positive relationships were recorded as follows: altruism versus extrinsic job satisfaction $(r=0.1365, p=0.0852)$ and intrinsic job satisfaction $(r=0.2604, p=0.1851)$; civic virtue versus extrinsic job satisfaction $(r=0.3420, p=0)$ and intrinsic job satisfaction $(r=0.3184$, $p=0.0003$ ); conscientiousness versus extrinsic job satisfaction $(r=0.0815, p=0.3056)$ and intrinsic job satisfaction $(r=0.0959, p=0.0744)$; and courtesy versus extrinsic job satisfaction $(r=0.2705, \quad p=0.0005)$ and intrinsic job satisfaction $(r=0.2847, p=0.0002)$. Only sportsmanship depicted a negative relationship with both extrinsic job satisfaction $(r=-0.5727, p=0)$ and intrinsic job satisfaction $(r=-0.5049, p=0)$. When all variables were combined together still a positive, but weak correlation was recorded between job satisfaction and OCB $(r=0.1382)$.

Table 4. Correlation matrix between change implementation, $O C B$ and job satisfaction

\begin{tabular}{|l|c|c|c|}
\hline \multicolumn{1}{|c|}{ Correlation section } & Change implementation & OCB & Job satisfaction \\
\hline Change implementation & 1 & 0.19 & 0.76 \\
\hline OCB & 0.19 & 1 & 0.14 \\
\hline Job satisfaction & 0.76 & 0.14 & 1 \\
\hline Cronbach's alpha 0.675866 Std. Cronbach's alpha 0.632256 \\
\hline
\end{tabular}




\section{Discussion}

The findings reported above validate previous research findings on the relationship between change implementation and OCB. Folger and Skarlicki (1999, p. 43) established a significant correlation between change and OCB. They reported that positive attitudes and citizenship behaviors are essential ingredients for effective change management. To add to this, Choi (2007, p. 467) investigated the relationship between workplace characteristics and change-oriented OCB. The study was conducted amongst 4,805 employees of a giant electronics company in Korea. His findings indicated that change-oriented OCB had a significant relationship with organizational variables such as strong vision and innovative climate. In other words, Choi (2007) established that employees' feelings or thought processes about the aforesaid variables somehow stimulated change oriented OCB. In line with Choi's (2007) findings, Zaccaro and Banks (2004, p. 367) comment that, even though there are not extensive empirical findings concerning the influence vision has on change-oriented OCB, few researchers have concluded that vision is a paramount stimulus of change success.

Following the results from the present study shown in Table 1, we can conclude that change was timeously planned, communicated and executed and employees actively participated and were rewarded for achieving the change vision. One can, therefore, conclude that well shared change vision stimulates change-oriented OCB. This could be the reason why, in this study, change was positively accepted and both managerial and non-managerial employees significantly adjusted to all forms of change. Investigations by Choi (2007, p. 480) on the relationship between supportive leadership, as a workplace characteristic, and changeoriented $\mathrm{OCB}$, found no significant relationship between the two variables. However, Bettencourt (2004, p. 169) found a significant relationship between the two. According to Smith et al. (1983, p. 653), leader supportiveness has a direct influence on OCB or can indirectly influence OCB through its effects on job satisfaction. In agreement, in their study carried out on a sample of petrochemical employees, Podsakoff et al. (1990, p. 107) found positive correlations between transformational leadership and OCB. More so, Konovsky and Organ (1996, p. 136) found that employee's citizenship behaviors are determined more by the leadership characteristics and the work environment, as opposed to by the employees' personality.

Comprehending the impact of change management on job satisfaction or job commitment constitutes one of the most paramount subject matters in organizational behavior (Gomes, 2009, p. 189). The results in Table 1 have confirmed that there is a strong relationship between change implementation and job satisfaction. According to Liu and Norcio (2008, p. 62), these results are consistent with previous research findings which acknowledge the significance of assessing the relevance of job satisfaction as a consequence of perceived change efficacy. Iwu et al's (2012) definition of employee satisfaction suggests that employee behaviors are directly influenced by the way the change process is administered or managed. In an attempt to establish the relationship between change management and job satisfaction, Alas (2007, p. 28) examined the effects of employee participation on job satisfaction during a change process among 41 companies with 1,398 respondents in Estonia. The findings revealed that satisfaction and participation are positively correlated, and employees with higher job satisfaction are more willing to participate in the organizational change process than employees with a lower job satisfaction level.

The strong positive relationship between change implementation and intrinsic job satisfaction $(r=0.6340)$ and extrinsic job satisfaction $(e=0.7634)$ indicate the significance of change management initiatives in promoting job satisfaction. With the overall result of this present study recording very strong positive relationship $(r=0.7644)$ between change implementation and job satisfaction, one can, therefore, conclude that there is a strong relationship between all change initiative variables and all job satisfaction variables. The aforementioned results correspond with the findings of Isa et al. (2011, p. 106) who investigated the correlation between change implementation initiatives and job satisfaction amongst 690 salespersons in the direct selling industry of Malaysia. Even though their findings failed to establish a positive relationship between job satisfaction and all change initiative variables, shared change vision, training and upline support positively correlated with job satisfaction.

Results from numerous experimental studies carried out to establish the relationship between OCB and job satisfaction have been inconsistent or contradictory. Nonetheless, 15 autonomous research findings across diverse contexts have established a positive correlation between the two variables (Organ \& Lingl, 1995, p. 339). Unlike the findings of Adam (2001), who found no correlation between job satisfaction and $\mathrm{OCB}$, the current research findings established a positive, but weak correlation between job satisfaction and OCB $(r=0.1382)$. These findings correspond and fortify previous research findings. Investigations by Chiboiwa (2010, p. 145) found a positive, but moderate correlation between job satisfaction and OCB $(r=0.198, p<0.05)$. His investigations were conducted among five organizations in Zimbabwe employing approximately 2,500 employees. 
Highlighting the efficacy of this relationship, Darmanto (2015) notes that OCBs are likely to be found among satisfied employees. Likewise, Werner ( 2007 , p. 1) notes that, the happier the employees, the greater the chances of them displaying positive behaviors which substantially promote organizational success. According to Bateman and Organ (1983, p. 587), job satisfaction triggers citizenship behaviors, as compared to other support systems provided by the organization. In line with this, Organ and Konovsky (1989) found that job satisfaction is the strongest measure that correlates with $\mathrm{OCB}$.

Following the above discussion, we can, therefore, conclude that the way employees comprehend change management and perceive it as beneficial to both the organization and the workforce, determines the magnitude of their satisfaction which, in turn, promotes citizenship behaviors. In agreement, Cohen (1999) maintains that employee behavior in organizations is directly influenced by the manner in which change is administered. After all, research has established that in order to enhance the manifestation of organizational citizenship behaviors in any organization, job satisfaction should be regarded as a vital mediating or moderating factor. Elaborating the aforementioned, Chiu and Chen (2005, p. 523) encourage organizations to create an enabling environment which compels employees to display citizenship behaviors. This is achieved by reinforcing the bond between job characteristics and OCB, and encouraging organizations to promote intrinsic job satisfaction in order for the workforce to exhibit citizenship behaviors.

Accoding to Podsakoff et al. (2000, p. 513), satisfied employees give back to their organizations by performing duties beyond their job descriptions or prescribed roles and responsibilities. Similarly, Gadot and Cohen (2004, p. 133) maintain that, due to the reciprocal exchange, or the 'give and take relationship between job satisfaction and OCB, it can be concluded that, in relation to the social exchange theory, in response to the way they are treated by their employers, employees can either display positive or negative citizenship behaviors. Also, Ghazzawi (2008, p. 4) investigated OCB as a potential consequence of job satisfaction. From his research findings and in line with the studies conducted by Organ and Ryan (1995, p. 775), he concluded that OCB is a product of job satisfaction.

Cognisant of a strong positive correlation between change implementation and job satisfaction and a positive, but moderate correlation between job satisfaction and OCB, we can confirm that well administered change initiatives stimulate job satisfaction which is an imperative OCB catalyst.

\section{Conclusion}

Globalization, driven by complex, ambiguous and burgeoning transformations, has seen many organizations embark on convoluted changes, such as restructuring, downsizing, business process reengineering, shared services, total quality management, mergers and acquisitions, just to keep the competitive edge.

In the flux of change, these organizations are increasingly challenged to balance the clamorous expectations of multiple stakeholders - investors, clients, management, customers and employees. Such constant change, without balance and consistency, is a double-edged sword which may lead to an anxious workforce and diminishing productivity. Cognisant of the above, it is worth remembering that the study examined the relationship between change implementation, organizational citizenship behavior and job satisfaction. Specifically, the study sought to achieve the following objectives: to examine the nature of change implementation in the BPO industry; to determine the effects of change implementation on OCB and job satisfaction in the BPO industry; to examine the relationship between change implementation, OCB and job satisfaction. Based on the research analyses and findings, it was established that there is a correlation between change implementation, OCB and job satisfaction.

As we draw this discussion to a close, we direct both researchers and practitioners to the following:

- Future studies should consider embracing a qualitative research approach to counter the limitations of the quantitative approach.

- Further replications of the study with a different sampling group or industry might provide a great deal of understanding of the concepts of job satisfaction, change management and OCB.

- There is little empirical research on the relationship between change implementation and OCB. Future research studies should explore the effects that change management types or initiatives have on $\mathrm{OCB}$, or ascertain whether change management influences all OCB variables.

Three other significant issues need to be pointed out regarding this study and these include:

1. the direct focus of the investigation on only the BPO industry raises concerns about limited generalizability. As a result, the study remains, in reality, not representative of all other industries;

2. the sample drawn from the BPO industry was only drawn in the Western Cape. Again, this betrays the concept of generalization; and

3. the number of participants in this study, although adequate for statistical testing, represents a relatively low response rate. 
For future research, a large sample size may be considered. Nonetheless, this study has established that in order to enhance the manifestation of organizational citizenship behaviors in any organization, job satisfaction should be regarded as a vital mediating or moderating factor. We can, therefore, conclude that the way employees understand change management and perceive it as beneficial to both the organization and the workforce, determines the magnitude of their satisfaction which, in turn, promotes citizenship behaviors. Pivotal to this is the need to highlight some practical and possibly theoretical implications of this study. Firstly, change management is inevitable in the BPO industry; therefore, organizations have to be constantly alert to tackle its demands. Secondly, the nature, extent and magnitude of its occurrence (i.e., change) vary from organization to organization; therefore, if not well managed, organizational change can become the greatest source of job dissatisfaction. And, finally, properly instituted change management initiatives significantly enhance the process of change and its success.

\section{References}

1. Adam, A.G. (2001). Antecedents of organizational citizenship behavior: a study of public personnel in Kuwait, Public Personnel Management, 30 (3), pp. 363-376.

2. Alas, R. (2007). The impact of employee participation on job satisfaction during change process, Problems and Perspectives in Management, 6(4), pp. 28-33.

3. Appelbaum, S.H., Gandell, J., Shapiro, B.T., Belisle, P. \& Hoeven, E. (2000). Anatomy of a merger: behavior of organizational factors and process throughout the pre- during- post-stage, Management Decision, 38 (10), pp. 674-684.

4. Barnard, C.I. (1938). The functions of the executive. Cambridge, MA: Harvard University Press.

5. Bateman, T.S. \& Organ, D.W. (1983). Job satisfaction and the good soldier: the relationship between affect and employee citizenship, Academy of Management Journal, 26, pp. 587-595.

6. Bettencourt, L.A. (2004). Change-oriented organizational citizenship behaviors: the direct and moderating influence of goal orientation, Journal of Retailing, 80 (3), pp. 165-180.

7. Boles, J., Madupalli, R., Rutherford, B. \& Wood, J.A. (2007). The relationship of facets of salesperson job satisfaction with affective organizational commitment, Journal of Business and Industrial Marketing, 22 (5), pp. 311-321.

8. Borman, W.C. (2004). The concept of organizational citizenship, Current Directions in Psychological Science, 13 (6), pp. 238-241.

9. Chan, J.M., Pan, Z. \& Lee, F.L.F. (2004). Professional aspirations and job Satisfaction: Chinese journalists at a time of change in the media, Journalism \& Mass Communication Quarterly, 81 (2), pp. 254-273.

10. Chiboiwa, M.C. (2011). Evaluation of job satisfaction and organizational citizenship behavior, African Journal of Business Management, 5 (7), pp. 2910-2918.

11. Chiu, S.F. \& Chen, H.L. (2005). Relationship between job characteristics and organizational citizenship behavior: the mediational role of job satisfaction, Social Behavior and Personality, 33 (6), pp. 523-540.

12. Choi, J.N. (2007). Change oriented organizational citizenship behavior: effects of work environment and intervening psychological process, Journal of Organizational Behavior, 28, pp. 467-484.

13. Chou, R.J.A. \& Robert, S.A. (2008). Workplace support, role overload, and job satisfaction of direct care workers in assisted living, Journal of Health and Social Behavior, 49 (2), pp. 208-222.

14. Cross, B. \& Travaglione, A. (2004). The times they are a-changing: who will stay and who will go in a downsizing organization? Personnel Review, 33 (3), pp. 275-290.

15. Cross, R., Rebele, R. \& Grant, A. (2016). Collaborative overload, Harvard Business Review, Jan-Feb, pp. 74-79.

16. Darmanto, S. (2015). Mediating Role of Jobs Satisfaction among Organizational Commitment, Organizational Culture and Organizational Citizenship Behavior (OCB): Empirical Study on Private Higher Education in Central Java, Indonesia, Journal of Research in Marketing, 4 (1), pp. 289-296.

17. Davis, G. (2004). Job satisfaction survey among employees in small businesses, Business and Enterprise Development, 11 (4), pp. 495-503.

18. Faulkenburg, K. \& Schyns, B. (2007). Work satisfaction, organizational commitment and withdrawal behaviors, Management Research News, 30 (10), pp. 708-723.

19. Folger, R. \& Skarlicki D.P. (1999). Unfairness and resistance to change: hardship as mistreatment, Journal of Organisational Change Management, 12, pp. 35-49.

20. Gadot, E.V. \& Cohen, A. (2004). Citizenship and management in public administration: integrating behavioral. London: Edward Elgar Publishers.

21. Ghazzawi, I. (2008). Job satisfaction antecedents and consequences: a new conceptual framework and research agenda, The Business Review, 11, pp. 1-10.

22. Gomes, D.R. (2009). Organisational change and job satisfaction: the mediating role of organisational commitment, Exedra Journals, 1, pp. 177-195.

23. Greenberg, J. \& Baron, R.A. (1995). Behavior in organisation: understanding and managing the human side of work. $5^{\text {th }}$ ed. London: Prentice Hall.

24. Griffeth, R.W., Gaermer, S. \& Sager, J.K. (2000). Taxonomic model of withdraw behaviors: the adaptive response model, Human Resource Management Review, 9, pp. 577-590.

25. Isa, F.M., Hin, C.W. \& Yunus, J.M. (2011). Change management initiatives and job satisfaction among salespersons in Malaysian direct selling industry, Asian Journal of Business and Management Sciences, 1 (7), pp. 106-121. 
26. Iwu, C.G., Ukpere, W.I. \& Allen-Ile, C. (2012). A model of employee satisfaction amongst health-related professionals in South Africa: The case of Western Cape Province, African Journal of Business Management, 6 (34), pp. 9658-9670.

27. Kanter, R.M., Stein, B.A. \& Jick, D.T. (1992). The challenge of organisational change. New York: The Free Press.

28. Kaplan, S.A., Warren, C.R., Barsky, A.P. \& Thorensen, C.J. (2009). A note on the relationship between affectivity and differing conceptualizations of job satisfaction: some unexpected meta-analytic findings, European Journal of Work and Organisational Psychology, 18 (1), pp. 29-54.

29. Karasek, R.A. (1979). Job demands, job decision latitude, and mental strain: implications for job redesign, Administrative Science Quarterly, 24 (2), pp. 285-308.

30. Katz, D. (1964). The motivational basis of organisational behavior, Behavioral Science, 9, pp. 131-146.

31. Konovsky, M.A. \& Organ, D.W. (1996). Dispositional and contextual determinants of organisational citizenship behavior, Journal of Organisational Behavior, 17, pp. 253-266.

32. Kotter, J.P. (1995). Leading change: why transformational efforts fail, Harvard Business Review, 73 (2), pp. 59-67.

33. Kreitner, R. \& Kinicki, A. (2004). Organisational behavior. London: MacGraw-Hill companies.

34. Liu, S. \& Norcio, R. (2008). Mediating effects of job characteristics on job satisfaction and organisational commitment of Taiwanese expatriates working in Mainland China, The Business Review, 9, pp. 62-69.

35. Locke, E.A. (1976). The nature and causes of job satisfaction. In Handbook of Industrial and Organizational Psychology. Ed. Dunnette, M. Chicago, IL, pp. 1297-1350.

36. Mack, D.A., Nelson, D.L. \& Quick, J.C. (1998). The stress of organisational change: a dynamic process model, Applied Psychology, 47 (2), pp. 219-232.

37. Organ, D.W. \& Konovsky, M. (1989). Cognitive versus affective determinants of organisational citizenship behavior, Journal of Applied Psychology, 74, pp. 157-164.

38. Organ, D.W. \& Lingl, A. (1995). Personality, satisfaction, and organisational citizenship Behavior, Journal of Applied Psychology, 135, pp. 339-350.

39. Organ, D.W. \& Near, J.P. (1985). Cognition versus affect in measures of job satisfaction, International Journal of Psychology, 20, pp. 241-253.

40. Organ, D.W. (1988). Organisational citizenship behavior: the good soldier syndrome. Toronto: Lexington Books.

41. Organ, D.W. (1997). Organisational citizenship behavior: it's construct clean-up time, Human Performance, 10 , pp. 85-101.

42. Organ, D.W. \& Ryan, K. (1995). A meta-analytic review of attitudinal and dispositional predictors of organisational citizenship behavior, Personnel Psychology, 48, pp. 775-802.

43. Podsakoff, P., Mackenzie, S., Paine, J. \& Bachrach, D. (2000). Organisational citizenship behaviors: a critical review of the theoretical and empirical literature and suggestions for future research, Journal of Management, 26 (3), pp. 513-563.

44. Porras, J.L. \& Robertson, P. (1992). Organisational development: theory, practice, and research. In Dunette, M.D. \& Hough, L.M. (Eds). Handbook of industrial and organisational Psychology. $2^{\text {nd }}$ ed. Palo Alto, CA: Consulting Psychological Press.

45. Reichers, A., Wanous, J.P. \& Austin, J.T. (1997). Understanding and managing cynicism about organisational change, The Academy of Management Executive, 11, pp. 48-66.

46. Schultz, H., Potgieter, T., Viedge, C. \& Werner, A. (2003). Organisational behavior. Pretoria: Van Schaik Publishers.

47. Svensen, E., Neset, G. \& Eriksen, H.R. (2007). Factors associated with a positive attitude towards change among employees during the early phase of a downsizing process, Scandinavian Journal of Psychology, 4, pp. 153-159.

48. Terry, D.J. \& Jimmieson, N.L. (2003). A stress and copying approach to organisational change: evidence from three field studies, Australian Psychologist, 30 (2), pp. 92-101.

49. Vakola, M. \& Nikolaou, I. (2005). Attitudes towards organisational change: what is the role of employees' stress and commitment? Employee Relations, 27 (1/2), pp. 160-174.

50. Van Emmeriki, I.J.H., Jawahar, I.M. \& Stone, T.H. (2005). Associations among altruism, burnout dimensions, and organisational citizenship behavior, Work \& Stress, 19 (1), pp. 93-100.

51. VanYperen, N.W., Van den Berg, A.E. \& Willering, M.C. (1999). Towards a better understanding of the link between participation in the decision-making and organisational citizenship behavior: a multilevel analysis, Journal of Occupational and Organisational Psychology, 72, pp. 377-392.

52. Weber, P.S. \& Weber, J.E. (2001). Changes in employee perceptions during organisational change, Leadership \& Organisation Development Journal, 22 (6), pp. 291-300.

53. Weiss, DJ., Dawis, RV., Lofquist, LH. \& England, G.H. (1966). Instrumentation for the theory of work adjustment. Minneapolis: Industrial Relations Center (Minnesota Studies in Vocational Rehabilitation, XXI).

54. Werner, A. (2007). Organisational behavior: a contemporary South African perspective. Pretoria: Van Schaik Publishers.

55. Williams, L.J. \& Anderson, S.E. (1991). Job satisfaction and organisational commitment as predictors of organisational citizenship and in-role behaviors, Journal of Management, 17 (3), pp. 601-617.

56. Wood, T.C. (2000). Mudança organizacional. São Paulo: Atlas.

57. Zaccaro, S.J. \& Banks, D. (2004). Leader visioning and adaptability: bridging the gap between research and practice on developing the ability to manage change, Human Resource Management, 43, pp. 367-380. 